\title{
Can Green Finance Optimize Energy Structure: A Spatial Econometric Analysis based on China's Traditional and Renewable Energy Consumption
}

Hui Wang

Yunnan Normal University

Lili Jiang

Suqian College

Hongjun Duan

Jiangsu Vocational and Technical College of Economics and Finance

Yifeng Wang ( $\square$ wyf870403@163.com )

Suqian College https://orcid.org/0000-0003-3573-2212

Yichen Jiang

zhejiang science and technology information research institute

\section{Research Article}

Keywords: Green finance, Renewable Energy consumption, Entropy weight method, Spatial Durbin model, Direct effect

Posted Date: December 1st, 2021

DOI: https://doi.org/10.21203/rs.3.rs-1087594/v1

License: (9) This work is licensed under a Creative Commons Attribution 4.0 International License.

Read Full License 
6 a. Pan-Asia Business School, Yunnan Normal University, Kunming, China,

7 b. Business School, Suqian College, Suqian, China,

8 c. School of Finance, Jiangsu Vocational College of Finance and Economics, Huaian, China,

9 d. Zhejiang science and Technology Information Research Institute, Hangzhou, China.

10 corresponding author: Yifeng Wang, Email: wyf870403@163.com 


\section{Can Green Finance Optimize Energy Structure: A Spatial Econometric Analysis based on China's Traditional and Renewable Energy Consumption}

Abstract: This paper studies the impact of the development of green finance on China's energy consumption structure. In terms of the construction of the green finance index (GFI), this paper selects 17 basic indexes from the three aspects of economy, finance, and environment, uses the improved entropy weight method to construct the GFI, and studies the spatial spillover effect of the GFI of China's provinces. This paper further studies the impact of green finance on traditional and renewable energy consumption. We first uses panel regression to determine that the development of green finance has a positive effect on the slowdown of traditional energy consumption and acceleration of renewable energy consumption, and then further studies the spatial characteristics of green finance development on energy consumption by using spatial Durbin model. The results show that there is a positive spatial spillover effect in the development of green finance among provinces in China. The development of green finance contributes to the conversion of traditional to renewable energy consumption. The effect of green finance on the transformation of energy consumption structure is mainly reflected in the direct effect. Therefore, the government should support the green finance, reduce traditional energy consumption and increase renewable energy consumption.

Keywords: Green finance; Renewable Energy consumption; Entropy weight method; Spatial Durbin model; Direct effect

\section{Introduction}

With the rapid development of countries across the world, energy consumption has become the main driving force of economic development. However, the massive consumption of energy has caused serious damage to the global ecological environment. People have criticized this kind of neglect and plunder of nature, and all countries have been called upon to develop renewable energy to maintain the balance of the ecological environment and reduce traditional energy consumption. In recent years, more and more countries have begun to realize the importance of renewable energy and environmental protection. For example, at the 19th National Congress of the Communist Party of China, facing the severe situation of tighter resource constraints, serious environmental pollution, and ecosystem degradation, there is a need to establish the concept of ecological civilization of respect for nature, to conform to nature and protect nature, and to implement a plan to ensure sustainable development. Japan put forward slogans such as "treat the environment well," "sustainable development," and "ecological way of life" to promote the concept of environmental education to the whole country, so as to deal with the increasingly complex environmental problems. In Germany, environmental protection policies have been deeply rooted in the hearts of the people. They adhere to the principle that whoever pollutes will govern, strive to achieve an environmentfriendly development model, and strive to live in harmony between man and nature. In order to better achieve the coordinated development of economy and environmental protection, people put forward the concept of green finance.

Green finance is generally regarded as an economic activity to support environmental 
improvement, climate change, and efficient use of resources, that is, financial services provided for project investment and financing, project operation, and risk management in environmental protection, energy conservation, clean energy, green transportation, green building, and other fields. Through financial services, green finance reduces the support for enterprises with high pollution and high energy consumption, encourages the development of environment-friendly enterprises, reduces the intensity of energy consumption, improves energy utilization, and optimizes the industrial structure of a nation, so as to realize the coordinated development of economic growth, green energy consumption, and environmental protection. In recent years, more and more countries have attached importance to the production and utilization of renewable energy, and the development of renewable energy has effectively improved the quality of economic development of all countries. At present, as the world's largest developing country, China's economic development and energy consumption are at the global forefront. It is of special significance to study the relationship between China's green finance development level and energy consumption structure. Therefore, it is of great theoretical and practical significance to empirically analyze the impact of China's green finance development on traditional and renewable energy consumption.

This paper will select the economic, financial, and environmental indicators of China's provinces through the improved entropy weight method to build China's Green Financial Development Index (GFI) and thereby measure the green financial development of China's provinces. This paper studies the spatial spillover effect of China's green finance development through the Moran index. More specifically, through the multiple regression model, panel regression model, and spatial Durbin model, this paper studies the impact of green finance development on traditional and renewable energy consumption. The results show that the development level of green finance in China's provinces is increasing yearly. There are obvious spatial inconsistencies in the development of green finance in China's provinces: The development of green finance in most provinces of China shows a positive spatial correlation, that is, there is a positive spatial spillover effect. Then, there is a negative correlation between the development of green finance and traditional energy consumption and a positive correlation between the development of green finance and renewable energy consumption, that is, the higher the development level of green finance, the lower the traditional energy consumption and the higher the renewable energy consumption.

\section{Literature review}

In 1974, Germany first established an environmental bank, namely the "ecological bank," to provide preferential lending policies for environmental protection projects. Salazar (1998) first proposed the concept of environmental finance and thought that with the worsening of environment, the economy would be hit. In order to promote the coordinated development of economy and environment, it is necessary to promote the ecological environment protection and economic growth through financial means. He also thought that environmental protection and the economy can be developed in coordination with each other, which is also regarded as the embryonic form of green finance development. Cowan (1999) further explains green finance on the basis of previous scholars. He thinks that green finance, as a financial innovation tool, is an interdisciplinary subject of financial theory and green economy. Green finance includes both the theory of financial and economic 
increasingly complex environmental problems, it can effectively solve the environmental pollution problem. White (2002) thinks that the development of green finance is very innovative. He fully absorbs the advantages of financial development and environmental protection and combines them organically. While economic development promotes the development of environmental protection, environmental protection promotes the development of high water levels and high quality of economy. Scholten (2006) studies the internal logic of economic sustainable development and ecological environment protection, proposing that green finance can effectively solve environmental pollution problems and make the economy develop continuously and efficiently through the innovation of various financial instruments, which is the best solution to solve environmental problems. Jeucken (2006) studies green development and financial development from the perspective of financial institutions, and further understands the intrinsic meaning of green finance. Rogger (2011) pointed out that with the worsening of ecological environment, countries should formulate corresponding strategies to deal with environmental problems; in developed countries in particular, they should realize sustainable economic development and ecological environment protection through green finance and other tools. Soundrarajan and Vivek (2016) proved the feasibility of green finance in India and discussed the impact of Green Finance on India's economic development and ecological environment protection. Taghizadeh hesari and Yoshino (2019) use the investment theory model, and through empirical analysis, they find that green finance has a strong spatial spillover effect; the higher the level of green finance development, the more beneficial it will be for investors. At the same time, the development of green finance can reduce risk and improve the return rate of green energy. In contrast to Jiang, et al. (2020), who use the entropy weight method to measure the GFI, this paper uses the method of annual measurement to calculate it. Because the GFI measured by entropy weight method is a relative index, this paper adopts the method of annual measurement to make the measurement result not time comparable.

At this stage, there is no research on the traditional and renewable energy consumption of green finance, but there is research on energy consumption of financial development. Some scholars believe that financial development plays a positive role in slowing down energy consumption. Shahbaz (2013) studied the long-term relationship between Malaysia's carbon dioxide emissions, financial development, and energy, found that financial development slowed down carbon dioxide emissions to a certain extent, and proved the relationship between the two through the Granger causality test. Abbasi (2016) used the ARDL method to study the long-term relationship between financial development and carbon emissions, and, through the vector error correction model and VECM, determined that financial variables had a greater impact on emission reduction. Khan (2017) explored the relationship between per capita greenhouse gas emissions and financial development by selecting the data of 34 middle and high-income countries in Asia and Europe. The study found that the effect of financial development on greenhouse gas emissions in each country is different, showing a negative correlation on the whole. La Rovere (2018) explored what the situation of greenhouse gas emissions in Brazil will be by 2050, and found that financial instruments can effectively reduce investment costs, and can effectively help Brazil out of poverty. Ameyaw (2019) analyzed time series data of the United States, China, Canada, and Nigeria from 1990 to 2016, found that financial development can effectively reduce carbon dioxide emissions, and through a machine learning method proved that countries can reduce carbon dioxide emissions to a very low level by 
2030.F Atsu (2021) studied the long-term relationship between energy consumption, financial

138 development and economic uncertainty in BRICs countries and found that policy uncertainty 139 increases carbon dioxide emissions, while financial development will reduce carbon dioxide 140 emissions. Ozturk (2021) studied the data of South African countries from 2000 to 2016, proving 141 that financial development can effectively improve the utilization rate of renewable energy. It is 142 necessary to strengthen the financial development of each country to cope with the increasingly 143 severe environmental problems. Francis (2021) studied the long-term relationship between energy 144 consumption, financial development, and economic policy uncertainty in Brazil, Russia, India, 145 China, and South Africa, and found that fossil fuel consumption and policy uncertainty lead to an 146 increase in carbon dioxide emissions.

147 The development of renewable energy and finance can effectively reduce carbon dioxide 148 emissions. However, some scholars have come to different conclusions. Some believe that the 149 development of finance cannot reduce traditional energy consumption but will instead increase the 150 level of traditional energy consumption. Shao (2017) used the data of 150 economies from 1970 to 1512010 to observe that the use of materials and fossil fuels will decrease in economic recession and 152 increase in the use of fossil materials in economic prosperity. Therefore, there is a positive 153 correlation between economic development and traditional energy consumption. Charfeddine (2019) 154 selected the data of 24 countries in the Middle East and North Africa and found that the explanation 155 of financial development on carbon dioxide emissions and energy consumption is low, and financial 156 development cannot reduce energy consumption and carbon dioxide emissions. Acheampong (2019) 157 found that energy consumption, trade openness, urbanization, and economic growth can increase 158 carbon emissions to a certain extent.

159 From the existing research, we can see that the impact of financial development on energy 160 consumption is not consistent, and the impact of green finance on traditional and renewable energy 161 consumption is scarcer. Therefore, based on the current research situation, this paper studies the 162 impact of green finance on energy consumption by constructing the GFI, and carries out the research 163 from an empirical point of view.

\section{The development of green finance and its theoretical analysis on energy consumption}

Green finance is generally regarded as guiding funds from enterprises with high pollution and high energy consumption to enterprises with low pollution and low energy consumption through financial instrument innovation. Its ultimate goal is to achieve harmonious economic and environmental development. The development of green finance can promote the optimization and upgrading of industrial structure, promote the development of technology, improve the use efficiency of energy, and reduce the consumption of fossil fuels such as coal. The impact of green financial development on energy consumption is mainly reflected in three aspects: industrial structure upgrading, technology optimization and policy support.The relationship is shown in Figure 1

(1) Industrial structure upgrading. With the development and progress of science and technology, the original development mode and energy acquisition mode no longer match the

178 the needs of modern people for high-quality life. Therefore, green finance has come into people's 179 vision. Green finance realizes the harmonious coexistence of economy and environment through 
financial instruments. Green finance helps enterprises embark on the road of industrial structure

181 optimization and upgrading through financial support, and finally realizes the adjustment of energy consumption structure.

183 (2) Technical optimization. With China's continuous emphasis on green development, high emission enterprises have been continuously restricted. The development of green finance gives enterprises more funds and opportunities to seek the upgrading of energy technology. The upgrading of technology improves the use efficiency of all kinds of energy, reduces energy waste, and finally achieves the purpose of reducing energy consumption. The progress of different energy use technologies has also adjusted the energy use structure to a great extent.

(3) Policy support. As China pays more and more attention to the development of green finance, green finance has received great policy support. This policy support sends signals to financial institutions, enterprises and individuals, promotes people from all parties to pay attention to green development enterprises and gives more financial support to green enterprises. With the market's attention and support for green enterprises, green enterprises can develop rapidly, accelerate enterprise technology development and industrial upgrading, so as to realize the upgrading of energy consumption structure and promote social development to be more green and efficient.

Figure 1 Theoretical mechanism of green finance affecting energy consumption structure

\section{Index selection and model construction 4.1 Selection of basic indicators}

In order to accurately measure the development of green finance, 17 basic indicators are selected on the basis of the existing research(Jiang,L,2020), and the development level of green finance in China's provinces is studied from the perspectives of the economy, environment, and finance, respectively, as shown in Table 1.

Table 1. Indicator system of China's green finance development level

\begin{tabular}{cccc}
\hline Dimension & Basic Indicator & Attribute & Calculation method \\
\hline Economic & Unemployment rate & - & Unemployment / \\
\hline
\end{tabular}




\begin{tabular}{|c|c|c|c|}
\hline \multirow[t]{3}{*}{ Dimension } & & & (Unemployment + employees) \\
\hline & Per capita gross regional product & + & $\begin{array}{l}\text { Gross regional product / regional } \\
\text { population }\end{array}$ \\
\hline & Per capita disposable income & + & $\begin{array}{l}\text { Regional total disposable } \\
\text { income / regional population }\end{array}$ \\
\hline $\begin{array}{l}\text { Environme } \\
\text { ntal }\end{array}$ & $\begin{array}{l}\text { Wastewater discharge per unit of } \\
\text { financial resources }\end{array}$ & - & $\begin{array}{l}\text { Wastewater discharge / (Deposit } \\
+ \text { Loan) }\end{array}$ \\
\hline \multirow[t]{5}{*}{ Dimensions } & $\begin{array}{l}\text { Sulfur dioxide emissions per unit of } \\
\text { financial resources }\end{array}$ & - & $\begin{array}{c}\mathrm{SO}_{2} \text { emissions / (Deposit }+ \\
\text { Loan) }\end{array}$ \\
\hline & $\begin{array}{l}\text { Solid waste output per unit of } \\
\text { financial resources }\end{array}$ & - & $\begin{array}{l}\text { Solid waste output / (Deposit + } \\
\text { Loan) }\end{array}$ \\
\hline & $\begin{array}{l}\text { Energy consumption per unit of } \\
\text { financial resources }\end{array}$ & - & $\begin{array}{l}\text { Energy consumption/ (Deposit } \\
+ \text { +Loan) })\end{array}$ \\
\hline & $\begin{array}{l}\text { Coverage rate of nature reserves } \\
\text { under unit of financial resources }\end{array}$ & + & $\begin{array}{l}\text { Area of Natural Reserve / } \\
\quad(\text { deposit }+ \text { loan })\end{array}$ \\
\hline & $\begin{array}{l}\text { Forest coverage per unit financial } \\
\text { resources }\end{array}$ & + & $\begin{array}{l}\text { Forest coverage / (deposit }+ \\
\text { loan) }\end{array}$ \\
\hline \multirow[t]{8}{*}{$\begin{array}{l}\text { Financial } \\
\text { Dimension }\end{array}$} & $\begin{array}{l}\text { Number of banking institutions per } \\
\text { area }\end{array}$ & + & $\begin{array}{c}\text { Number of banking institutions / } \\
\text { regional area }\end{array}$ \\
\hline & $\begin{array}{c}\text { Number of banking employees per } \\
\text { area }\end{array}$ & + & $\begin{array}{c}\text { Number of banking employees / } \\
\text { regional area }\end{array}$ \\
\hline & $\begin{array}{l}\text { Average number of banking } \\
\text { institutions per resident }\end{array}$ & + & $\begin{array}{c}\text { Number of banking institutions / } \\
\text { number of regions }\end{array}$ \\
\hline & $\begin{array}{l}\text { Average number of banking } \\
\text { employees of residents }\end{array}$ & + & $\begin{array}{l}\text { Number of banking practitioners } \\
\text { / regional population }\end{array}$ \\
\hline & Bank deposit & + & $\begin{array}{l}\text { Deposit balance of financial } \\
\text { institutions / GDP }\end{array}$ \\
\hline & Bank loans & + & $\begin{array}{l}\text { Loan balance of financial } \\
\text { institutions / GDP }\end{array}$ \\
\hline & Insurance density & + & $\begin{array}{l}\text { Premium income / number of } \\
\text { people }\end{array}$ \\
\hline & Insurance depth & + & Premium income / GDP \\
\hline
\end{tabular}

\subsection{Improved entropy weight method}

223 When measuring the development index of China's green finance, this paper selects the improved entropy weight method based on the research of Jin (2017), Lei and Qiu (2016), Min (2019), Weiwei

225 (2018), and Jiang et al. (2020).

Suppose that $\mathrm{m}$ provinces are selected to measure their GFI, $\mathrm{n}$ basic indexes are selected, and the $j-t h$ index of the $i-t h$ province is $x_{i j}$. This paper constructs the matrix of basic indicators of GFI, processes the positive and negative indicators, respectively, and obtains the standardized matrix by using the following formula: $r_{i j}, 0 \leq r_{i j} \leq 1$ 


$$
X=\left(x_{i j}\right)_{m \cdot n}=\left(\begin{array}{ccc}
x_{11} & \mathrm{~K} & x_{1 n} \\
\mathrm{M} & \mathrm{O} & \mathrm{M} \\
x_{m 1} & \mathrm{~L} & x_{m n}
\end{array}\right)_{m \cdot n}
$$

$$
r_{i, j}= \begin{cases}\frac{x_{i j}-\min x_{i j}}{\max x_{i j}-\min x_{i j}} & \text { if } \mathrm{x}_{i j} \text { is a positive indicator. } \\ \frac{\max x_{i j}-x_{i j}}{\max x_{i j}-\min x_{i j}} & \text { if } \mathrm{x}_{i j} \text { is a negative indicator. }\end{cases}
$$

Calculate the GFI $C_{i}$ of different provinces in China:

$s_{i}^{+}$and $s_{i}^{-}$are the Euclidean distance. The higher $G F I_{i}$ value, the higher the level of green

finance development; the lower $G F I_{i}$ value, the lower the level of green finance development.

\subsection{The spatial spillover effect of green finance development}

Moran's I is a key index to test the spatial spillover effect of the GFI. In this model, the original assumption is that there is no spatial autocorrelation between the green financial development of China's provinces. When the original assumption is not tenable, it means that there is a spatial autocorrelation between the green financial development of China's provinces. The value of the Moran index is generally between $[-1,1]$; greater than 0 means positive correlation, less than 0 means negative correlation. The calculation of the Moran index is shown in Formulas (4) and (5)

$$
I=\frac{\sum_{i=1}^{n} \sum_{j=1}^{n} w_{i j}\left(x_{i j}-\bar{X}\right)\left(x_{j}-\bar{X}\right)}{S^{2} \sum_{i=1}^{n} \sum_{j=1}^{n} w_{i j}}
$$

$$
S^{2}=\frac{\sum_{i=1}^{n}\left(x_{i}-\bar{X}\right)^{2}}{n}
$$

$w_{i j}$ is the spatial weight matrix and $\mathrm{S}^{2}$ is the sample variance.

It is necessary to test the local Moran index and depict the local Moran scatter diagram to see whether there is heterogeneity and correlation in the development of green finance between each

$$
\mathrm{I}_{i}=\frac{\left(x_{i}-\bar{X}\right) \sum_{i=1}^{n} W_{i j}\left(x_{j}-\bar{X}\right)}{S^{2} \sum_{i=1}^{n} \sum_{j=1}^{n} W_{i j}}
$$


When the Moran index is positive, it indicates that there is a positive spatial correlation between the development of green finance in China's provinces; when it is negative, it indicates that there is a negative spatial correlation.

4.3 Model setting

Firstly, this paper uses a multivariate linear regression model to study the impact of China's green finance development on energy consumption

renewable energy consumption, $G F I_{i}$ represents the level of green finance development, and $X_{i}$

represents the i-th control scalar; $\varepsilon_{i}$ is the error term.

Secondly, considering that the sample data selected in this paper have obvious panel characteristics, this paper uses a panel regression model to study the impact of China's green finance development on energy consumption.

$$
\begin{aligned}
& \text {TEC }_{i}=\alpha+\beta_{1} G F I_{i}+\beta X_{i}+\varepsilon_{i} \\
& R E C_{i}=\alpha+\beta_{1} G F I_{i}+\beta X_{i}+\varepsilon_{i}
\end{aligned}
$$

$T E C_{i}$ represents the level of traditional energy consumption, $R E C_{i}$ represents the level of

There are three common spatial econometric models: the spatial error model (SEM), spatial autoregressive model (SAR) and spatial Durbin model (SDM).

The SEM model only contains the spatial autocorrelation term of error term:

$$
\begin{gathered}
\lambda \neq 0 \quad \varepsilon_{\mathrm{it}}=\lambda W_{i} \varepsilon_{t}+v_{i t} \\
T E C_{i t}=u_{i}+\gamma_{i}+\beta_{0} G F I_{i t}+\beta X_{i t}+\varepsilon_{i t}
\end{gathered}
$$




$$
R E C_{i t}=u_{i}+\gamma_{i}+\beta_{0} G F I_{i t}+\beta X_{i t}+\varepsilon_{i t}
$$

SAR models usually contain the spatial autocorrelation terms of the explained variables:

$$
\begin{array}{ccc}
\lambda=0 & \varepsilon_{i t}=v_{i t} \quad \rho \neq 0 \quad \beta=0 \\
T E C_{i t}=u_{i}+\gamma_{i}+\rho W_{i} T E C_{t}+\beta_{0} G F I_{i t}+\beta X_{i t}+v_{i t} \\
R E C_{i t}=u_{i}+\gamma_{i}+\rho W_{i} R E C_{t}+\beta_{0} G F I_{i t}+\beta X_{i t}+v_{i t}
\end{array}
$$

In SDM model, the spatial autocorrelation of explanatory variables is added under the limitation of SAR model:

$$
\begin{gathered}
\lambda=0 \quad \varepsilon_{\mathrm{it}}=v_{i t} \quad \rho \neq 0 \quad \beta \neq 0 \\
T E C_{\mathrm{it}}=u_{i}+\gamma_{i}+\rho W_{i} T E C_{t}+\beta_{0} W_{i} G F I_{t}+\beta_{1} \mathrm{~W}_{i} X_{t}+\beta_{2} G F I_{i t}+\beta X_{i t}+v_{i t} \\
R E C_{\mathrm{it}}=u_{i}+\gamma_{i}+\rho W_{i} R E C_{t}+\beta_{0} W_{i} G F I_{t}+\beta_{1} \mathrm{~W}_{i} X_{t}+\beta_{2} G F I_{i t}+\beta X_{i t}+v_{i t}
\end{gathered}
$$

In this paper, the LM Test, Hausmann test, Wald test, and joint significance test are used to determine the specific model.

\subsection{Variable selection}

Before the empirical analysis, the appropriate variables, i.e., those directly related to the results of the empirical analysis, must be chosen. In prior studies, the impact of each variable on energy consumption is not consistent, and there is no complete consensus as to each variable on reducing energy consumption. Based on the existing research, this paper selects the following variables and gives a theoretical mechanism of each variable on energy consumption based on empirical analysis.

(1) Explained variable

Energy consumption (ECI). The logarithm of coal consumption is selected as the proxy variable of energy consumption. By 2020, China's coal consumption reached $29 \%$ of the global consumption, making China whose main energy source is coal the largest coal consumer in the world. In China's energy consumption structure, coal consumption accounted for $57.7 \%$ in 2020 . Therefore, this paper will select the logarithm of coal consumption as the explained variable to measure China's energy consumption level.

(2) Explanatory variable

Green finance development level (GFI). The GFI is our core explanatory variable, but there is no unified conclusion on whether the development of green finance helps to reduce energy consumption. On the one hand, when the development level of green finance rises, the economy realizes sustainable development, promotes coordination, sustainability, and equality, and helps to reduce energy consumption. On the other hand, when the development level of green finance increases, the environmental protection requirements of the industry will increase additional costs, which will lead to more difficult operation of enterprises and may reduce the implementation of environmental protection projects. Therefore, it must be determined whether the development of green finance helps to reduce energy consumption.

(3) Control variables

Urbanization level (LUR). We found that the development of a region is often from led by the high pollution and high energy consumption enterprises. With the continuous development of the economy, the industrial structure is upgraded, the enterprises with high pollution and high energy consumption are gradually eliminated, and the population of urbanization and tertiary industry are increased. Therefore, the use of urbanization level as a control variable can effectively improve and explain the model. 
Industrial structure (ISI). Energy consumption is mainly concentrated in the secondary industry, industry often needs a lot of coal consumption, so the industrial structure of the secondary industry is of great significance for the study of energy consumption. When the development of green finance promotes the optimization and upgrading of industrial structure and realizes the latter, the use of industrial structure as a control variable can be effectively studied. This paper selects the logarithm of the added value of the second industry as the control variable to measure the change in industrial structure.

Government intervention level (LGV). In order to achieve the sustainable development of the economy and environment, when the government intervention increases, it will be conducive to the implementation of green finance policy; at the same time, it will give more financial support to green enterprises, help enterprises complete the upgrading of industrial structure, and promote the better development of economy and environment. This paper selects the logarithm of government expenditure to represent the level of government intervention in economy.

Economic Openness (loprn). When the degree of economic openness continues to improve, it is conducive to the increase of domestic exports, the continuous improvement of domestic employment, and the development of high-end technology, so as to increase the efficiency of energy use and reduce energy consumption. In this paper, the logarithm of total import and export is used to express the degree of economic openness.

340 Generalized technological progress (TPI). In a broad sense, technological progress usually 341 refers to the accumulation and improvement of various forms of knowledge covered by technology.

342 The higher the education level of people, the higher the level of science and technology, and the 343 higher the energy utilization rate. In this paper, the logarithm of the average number of students per 344100,000 people in Colleges and universities is selected to represent the proxy variable of generalized 345 technological progress.

Specific indicators are shown in Table 2

Table 2. Definitions of main variables

\begin{tabular}{cccc}
\hline Variable & $\begin{array}{c}\text { Variable } \\
\text { name }\end{array}$ & Variable meaning & Variable method \\
\hline $\begin{array}{c}\text { Explained } \\
\text { variable }\end{array}$ & TEC & $\begin{array}{c}\text { Traditional energy } \\
\text { consumption } \\
\text { renewable energy } \\
\text { consumption }\end{array}$ & Logarithm of coal consumption \\
\hline $\begin{array}{c}\text { Explanatory } \\
\text { variable }\end{array}$ & GEC & $\begin{array}{c}\text { Green financial } \\
\text { development level }\end{array}$ & Green finance development index \\
\hline $\begin{array}{c}\text { Gontrol } \\
\text { variable }\end{array}$ & LUR & $\begin{array}{c}\text { Urbanization } \\
\text { level }\end{array}$ & Logarithm of urban population \\
& LGV & $\begin{array}{c}\text { Industrial structure } \\
\text { Level of government } \\
\text { intervention in } \\
\text { economy }\end{array}$ & Logarithm of added value of secondary \\
& LOPRN & Economic Openness & Logarithm of government expenditure \\
& Logarithm of total import and export
\end{tabular}


Technological

TPI

progress in broad

Logarithm of the average number of

students in secondary and tertiary

institutions per 100,000 people

348

\section{Empirical analysis}

\subsection{Data selection and processing}

This paper selects the relevant indicators from 2004 to 2019 to build China's GFI. The data are processed as follows: (1) The data of 25 provinces and municipalities in China are selected for empirical analysis. According to the availability of data, Hong Kong, Macao, Taiwan, Tibet, Xinjiang, Ningxia, Guangxi, Neimenggu, Hainan, and other regions are excluded; (2) This paper uses the linear interpolation method to supplement some missing values in the data; (3) The data comes from the statistical yearbooks of China's provinces and their annual financial operation reports. The descriptive statistical results of the data are shown in Table 3.

Table 3. Descriptive statistics of variables

\begin{tabular}{|c|c|c|c|c|c|c|}
\hline Variable & $\begin{array}{c}\text { Variable } \\
\text { name }\end{array}$ & Sample & $\begin{array}{c}\text { Average } \\
\text { value }\end{array}$ & $\begin{array}{c}\text { Standard } \\
\text { deviation }\end{array}$ & Minimum & Maximum \\
\hline TEC & $\begin{array}{c}\text { Traditional energy } \\
\text { consumption }\end{array}$ & 400 & 4.003 & 0.3520 & 2.690 & 4.704 \\
\hline REC & $\begin{array}{c}\text { renewable energy } \\
\text { consumption }\end{array}$ & 400 & 1.838 & 0.984 & -1.523 & 3.521 \\
\hline GFI & $\begin{array}{c}\text { Green financial } \\
\text { development level }\end{array}$ & 400 & 0.223 & 0.056 & 0.157 & 0.476 \\
\hline LUR & Urbanization level & 400 & 0.543 & 0.148 & 0.263 & 0.896 \\
\hline ISI & Industrial structure & 400 & 0.479 & 0.263 & 0.038 & 4.046 \\
\hline LGV & $\begin{array}{c}\text { Level of government } \\
\text { intervention in } \\
\text { economy }\end{array}$ & 400 & 2.588 & 0.730 & 0.615 & 4.038 \\
\hline LOPRN & Economic Openness & 400 & 3.435 & 0.374 & 2.137 & 4.237 \\
\hline TPI & $\begin{array}{c}\text { Technological progress } \\
\text { in broad sense }\end{array}$ & 400 & 3.358 & 0.174 & 2.872 & 3.838 \\
\hline
\end{tabular}

\subsection{Empirical results of the GFI}

362 Table 4 and Figure 1 report the GFI of China's provinces. Overall, China's GFI is increasing yearly. 363 There are some differences in the development level of green finance among different regions in 364 China: Shanghai, Beijing, Guangdong, Jiangsu, and Zhejiang have higher initial development level 365 of green finance and show a trend of yearly increase. In Qinghai, Guizhou, Yunnan, Gansu, and 366 Jiangxi, the initial green finance development level is relatively low and the growth rate is relatively 367 slow. 
Table 4. GFI of China's provinces from 2004 to 2019

\begin{tabular}{|c|c|c|c|c|c|c|c|c|}
\hline Province & 2004 & $\ldots$ & 2014 & 2015 & 2016 & 2017 & 2018 & 2019 \\
\hline Beijing & 0.242 & .. & 0.347 & 0.367 & 0.395 & 0.408 & 0.405 & 0.428 \\
\hline Tianjin & 0.233 & $\ldots$ & 0.273 & 0.283 & 0.296 & 0.303 & 0.306 & 0.302 \\
\hline Hebei & 0.165 & $\ldots$ & 0.210 & 0.227 & 0.244 & 0.263 & 0.235 & 0.249 \\
\hline Shanxi & 0.165 & $\ldots$ & 0.192 & 0.204 & 0.215 & 0.218 & 0.267 & 0.283 \\
\hline Liaoning & 0.198 & $\ldots$ & 0.223 & 0.233 & 0.246 & 0.252 & 0.246 & 0.253 \\
\hline Jilin & 0.232 & $\ldots$ & 0.196 & 0.201 & 0.211 & 0.218 & 0.217 & 0.225 \\
\hline Heilongjiang & 0.203 & $\ldots$ & 0.191 & 0.197 & 0.204 & 0.216 & 0.216 & 0.229 \\
\hline Shanghai & 0.267 & $\ldots$ & 0.417 & 0.413 & 0.428 & 0.432 & 0.457 & 0.476 \\
\hline Jiangsu & 0.189 & $\ldots$ & 0.260 & 0.274 & 0.294 & 0.269 & 0.316 & 0.330 \\
\hline Zhejiang & 0.201 & $\ldots$ & 0.278 & 0.287 & 0.299 & 0.310 & 0.316 & 0.330 \\
\hline Anhui & 0.182 & $\ldots$ & 0.199 & 0.210 & 0.220 & 0.235 & 0.235 & 0.236 \\
\hline Fujian & 0.234 & $\ldots$ & 0.215 & 0.221 & 0.229 & 0.237 & 0.240 & 0.250 \\
\hline Jiangxi & 0.187 & $\ldots$ & 0.194 & 0.198 & 0.204 & 0.211 & 0.212 & 0.220 \\
\hline Shandong & 0.187 & $\ldots$ & 0.231 & 0.239 & 0.264 & 0.284 & 0.274 & 0.293 \\
\hline Henan & 0.201 & $\ldots$ & 0.218 & 0.229 & 0.243 & 0.274 & 0.269 & 0.270 \\
\hline Hubei & 0.240 & $\ldots$ & 0.200 & 0.210 & 0.215 & 0.231 & 0.237 & 0.247 \\
\hline Hunan & 0.194 & $\ldots$ & 0.190 & 0.198 & 0.207 & 0.215 & 0.226 & 0.237 \\
\hline Guangdong & 0.201 & $\ldots$ & 0.301 & 0.320 & 0.343 & 0.366 & 0.274 & 0.352 \\
\hline Chongqing & 0.259 & $\ldots$ & 0.194 & 0.204 & 0.205 & 0.215 & 0.233 & 0.239 \\
\hline Sichuan & 0.201 & $\ldots$ & 0.239 & 0.251 & 0.269 & 0.271 & 0.275 & 0.275 \\
\hline Guizhou & 0.259 & $\ldots$ & 0.175 & 0.180 & 0.186 & 0.193 & 0.195 & 0.199 \\
\hline Yunnan & 0.222 & $\ldots$ & 0.186 & 0.193 & 0.199 & 0.205 & 0.205 & 0.204 \\
\hline Shanxi & 0.207 & $\ldots$ & 0.194 & 0.202 & 0.209 & 0.216 & 0.228 & 0.229 \\
\hline Gansu & 0.166 & $\ldots$ & 0.186 & 0.195 & 0.203 & 0.202 & 0.202 & 0.204 \\
\hline Qinghai & 0.432 & $\ldots$ & 0.179 & 0.180 & 0.187 & 0.188 & 0.191 & 0.198 \\
\hline
\end{tabular}

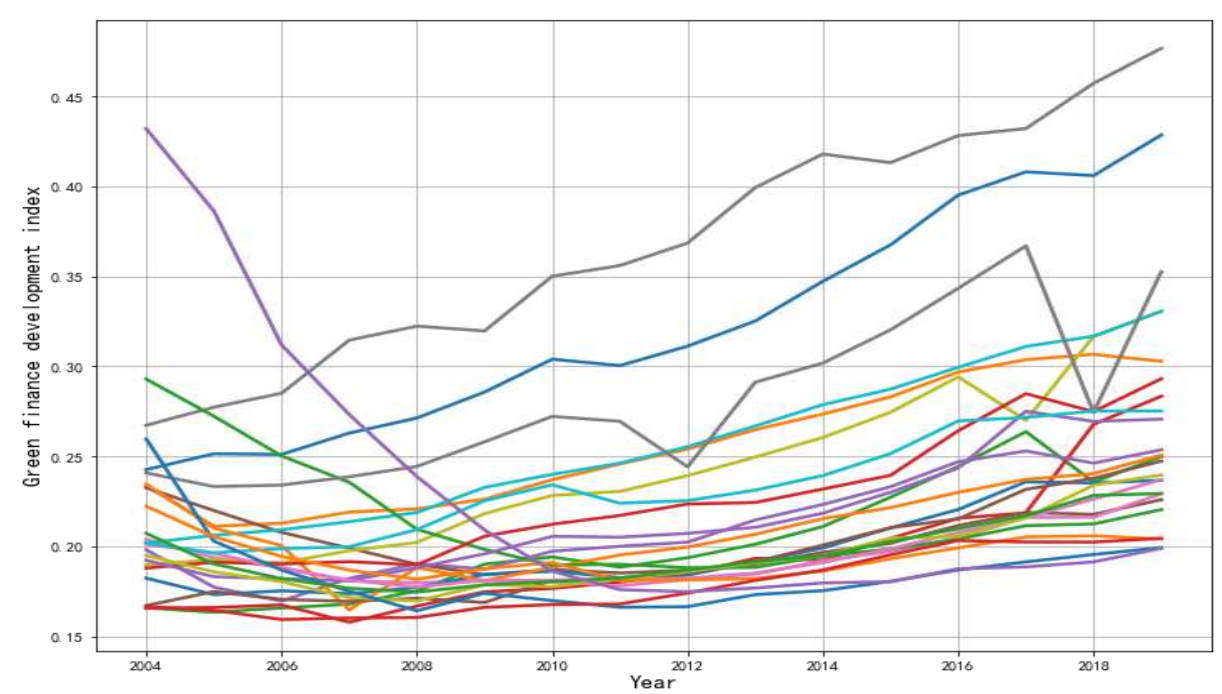


Further analysis shows that there is a strong spatial inconsistency in the development of green finance in China, and the development level of green finance in the eastern region is higher than that in the western region, which leads us to further analyze the spatial spillover effect of China's green finance development.

5.3 Spatial spillover effect of green finance development

Table 5 shows the Moran index of green finance development in China's provinces and the corresponding statistical test results. It is not difficult to observe that the Moran index from 2004 to 2007 is not significant; however, it has been gradually significant since 2008, and it shows the characteristics of positive spatial dependence.

Table 5. Moran test results of green finance in China

\begin{tabular}{lccc}
\hline Year & Moran's I & $\mathrm{Z}$ & Prob. \\
\hline 2004 & -0.102 & -0.508 & 0.306 \\
2005 & -0.080 & -0.314 & 0.377 \\
2006 & -0.023 & 0.134 & 0.447 \\
2007 & 0.031 & 0.523 & 0.300 \\
2008 & 0.133 & 1.309 & 0.095 \\
2009 & 0.184 & 1.667 & 0.048 \\
2010 & 0.186 & 1.703 & 0.044 \\
2011 & 0.234 & 2.067 & 0.019 \\
2012 & 0.291 & 2.534 & 0.006 \\
2013 & 0.258 & 2.267 & 0.012 \\
2014 & 0.266 & 2.319 & 0.010 \\
2015 & 0.268 & 2.268 & 0.012 \\
2016 & 0.267 & 2.227 & 0.013 \\
2017 & 0.220 & 1.872 & 0.031 \\
2018 & 0.319 & 2.691 & 0.004 \\
2019 & 0.277 & 2.327 & 0.01 \\
\hline
\end{tabular}

383

Taking the local Moran I scatter diagram of 2008 and 2019 as an example, the vast majority of provinces are in the first and third quadrants, which shows that the development of green finance in most provinces of China in the past two years have a positive spatial correlation. This positive correlation is that the development of green finance in each province has a positive spatial spillover effect, and the provinces with high levels of green finance development appear to be clustered. The provinces with low development levels of green finance also have agglomeration, that is, there is a trend of high agglomeration and low agglomeration. 


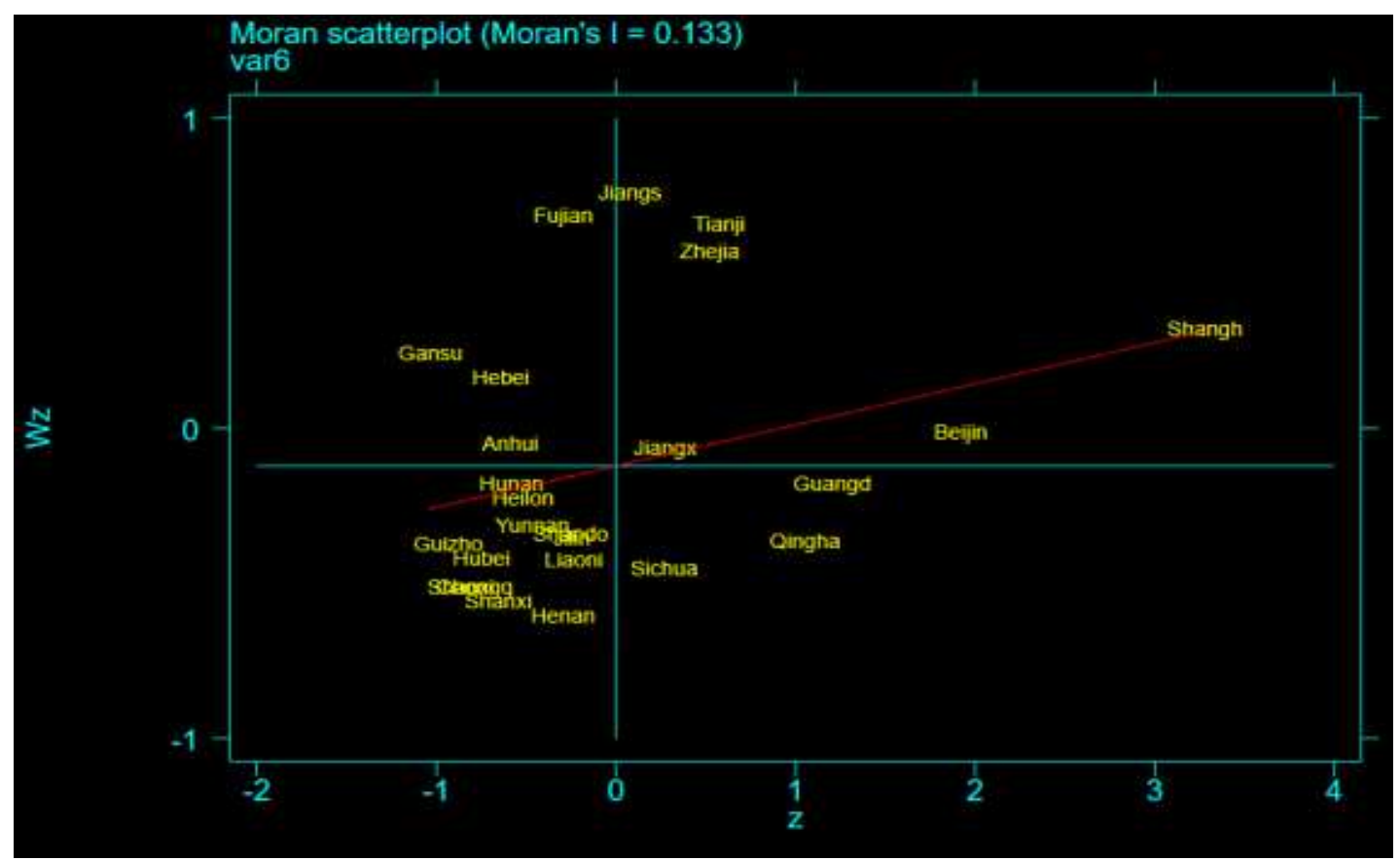

Figure 3. Moran I scatter plot of GFI in 2008

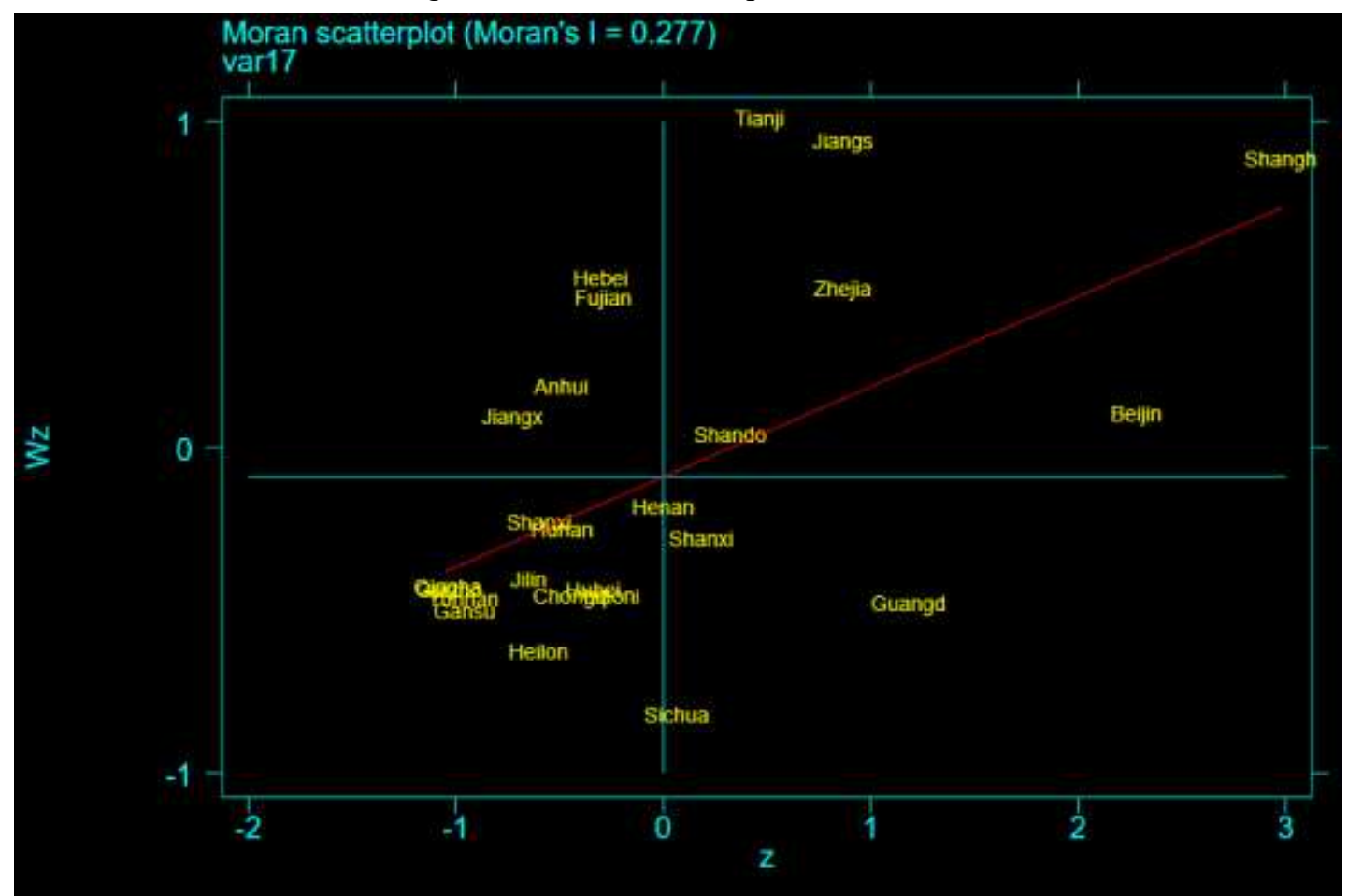

Figure 4. Moran I scatter plot of GFI in 2019

5.4 Multiple regression and static panel regression results of green finance development on energy consumption

399 This paper uses multiple regression and panel regression to analyze the impact of green finance on

400 energy consumption. The results of the Hausmann test are significant at the level of $1 \%$, so the fixed 401 effect model should be chosen. The results of the correlation test and regression are shown in Tables 4026 and 7. 
Table 6. Results of Hausmann test

\begin{tabular}{|c|c|c|c|}
\hline Explained variable & Test Summary & Chi-Sq. Statistic & Prob. \\
\hline TEC & Cross-section random & 123.925 & $\leqslant 0.001$ \\
\hline REC & Cross-section random & 689.730 & $\leqslant 0.001$ \\
\hline
\end{tabular}

404

405

\begin{tabular}{|c|c|c|c|c|}
\hline \multirow{2}{*}{ Variable } & \multicolumn{2}{|c|}{ TEC } & \multicolumn{2}{c|}{ REC } \\
\cline { 2 - 5 } & Multiple regression & Panel regression & Multiple regression & Panel regression \\
\hline GFI & $-2.301^{* * *}$ & $-0.901^{* * *}$ & $1.161^{* *}$ & $1.187^{* * *}$ \\
\hline LUR & $-1.318^{* * *}$ & $0.786^{* * *}$ & $-2.457^{* * *}$ & $0.922^{* *}$ \\
\hline ISI & 0.061 & 0.011 & 0.053 & -0.039 \\
\hline LGV & $0.318^{* * *}$ & 0.030 & $-0.325^{* * *}$ & $0.141^{* *}$ \\
\hline LOPRN & $0.349^{* * *}$ & $0.051^{* *}$ & $1.220^{* * *}$ & $0.122^{* *}$ \\
\hline TPI & 0.023 & $0.304^{* * *}$ & $-1.317^{* * *}$ & 0.138 \\
\hline Constant & $3.102^{* * *}$ & $2.493^{* * *}$ & $3.961^{* * *}$ & -0.162 \\
\hline $\mathrm{R}^{2}$ & 0.546 & 0.616 & 0.414 & 0.432 \\
\hline
\end{tabular}

406

407

408

409

410

411

412

413

414

Table 7. Results of multiple regression and static panel regression

$$
* \mathrm{p}<0.1, * * \mathrm{p}<0.05, * * * \mathrm{p}<0.01
$$

It can be found from Table 7 that regardless of whether multiple regression or panel regression is employed, there is a negative correlation between green finance development and traditional energy consumption, that is, the higher the level of green finance development, the lower the level of energy consumption. When the development level of green finance increased by $1 \%$, under multiple regression and panel regression, traditional energy consumption decreased by $2.301 \%$ and $0.901 \%$ respectively.

It also can be found that there is a positive correlation between green finance development and renewable energy consumption. The higher the level of green finance development, the higher the level of renewable energy consumption. When the development level of green finance increased by $1 \%$, under multiple regression and panel regression, renewable energy consumption increased by $1.161 \%$ and $1.187 \%$ respectively.

From the above analysis, we can see that the development of green finance is conducive to the upgrading of energy consumption structure. With the continuous improvement of China's green finance development, the consumption of traditional energy is gradually reduced, and the consumption of renewable energy is gradually increased. Therefore, the development of green finance can effectively improve the energy consumption structure. Through green finance, China improves energy consumption structure, reduces environmental pollution, and finally achieves sustainable development.

\subsection{Spatial econometric regression results of the impact of green finance development on} energy consumption

In the theoretical analysis part of this paper, we introduce the commonly used spatial econometric models and use the LM Test to determine whether to use the SEM model or SAR model. If we find that both are suitable, we need to consider the SDM model. At this time, we test the model through the Wald test and likelihood ratio test (LR). After determining the model, we carry out the Hausmann 
test to determine whether to use the fixed effect model or random effect model. For spatial econometrics, we also need to a conduct joint significance test, which is used to determine whether to use the individual fixed effect model or time fixed effect model. The specific empirical results are as follows.

Table 8. LM Test

\begin{tabular}{|c|c|c|c|}
\hline \multicolumn{2}{|c|}{} & Statistic & Prob. \\
\hline \multirow{2}{*}{ TEC } & LM-lag & 6.454 & 0.011 \\
\cline { 2 - 4 } & LM-err & 423.493 & $\leqslant 0.001$ \\
\hline \multirow{2}{*}{ REC } & LM-lag & 445.552 & $\leqslant 0.001$ \\
\cline { 2 - 4 } & LM-err & 131.601 & $\leqslant 0.001$ \\
\hline
\end{tabular}

Table 9. LR test, Wald test and Hausmann test

\begin{tabular}{|c|c|c|c|c|c|}
\hline \multicolumn{2}{|c|}{} & \multicolumn{2}{|c|}{ LR Test } & \multirow{2}{*}{ Wald Test } & Hausman Test \\
\cline { 3 - 4 } \multicolumn{2}{|c|}{} & SAR & SEM & & \\
\hline \multirow{2}{*}{ TEC } & Statistic & 19.570 & 16.720 & 16.970 & 21.690 \\
\cline { 2 - 5 } & Prob. & 0.003 & 0.010 & 0.009 & 0.060 \\
\hline \multirow{2}{*}{ REC } & Statistic & 37.17 & 38.19 & 39.770 & 20.060 \\
\cline { 2 - 4 } & Prob. & $\leqslant 0.001$ & $\leqslant 0.001$ & $\leqslant 0.001$ & 0.093 \\
\hline
\end{tabular}

438

439

\begin{tabular}{|c|c|c|c|}
\hline \multirow{2}{*}{ TEC } & & LR chi & Prob. \\
\hline \multirow{2}{*}{ REC } & Time & 242.720 & $\leqslant 0.001$ \\
\cline { 2 - 4 } & Ind & 67.490 & $\leqslant 0.001$ \\
\cline { 2 - 4 } & 1008.24 & 0 & 1008.24 \\
\hline
\end{tabular}

From the table 8 and table 9, the LM Test, the LR test and Wald test tell us that the Spatial Durbin model cannot be simplified as the spatial error model and spatial lag model. Therefore, this paper will use the Spatial Durbin model for research. From the results of the Hausmann test, the chi square statistic are 21.69 and 20.06, which passes the test at the level of $10 \%$. Therefore, a fixed effect model should be constructed. Finally, through the joint significance test, we can see that the double fixed model should be used. The results are shown in Table 11.

Table 11. Spatial Durbin model results of green finance on energy consumption

\begin{tabular}{|c|c|c|}
\hline & TEC & REC \\
\hline GFI & $-0.845^{* * *}$ & $1.309^{* * *}$ \\
\hline LUR & $1.332^{* * *}$ & -0.611 \\
\hline ISI & 0.013 & -0.036 \\
\hline LGV & $-0.079 * * *$ & -0.093 \\
\hline LOPRN & -0.032 & -0.059 \\
\hline TPI & $0.165^{* *}$ & 0.173 \\
\hline $\mathrm{R}^{2}$ & 0.2439 & 0.198 \\
\hline
\end{tabular}


The results of the spatial econometric regression further confirm that the development of green finance can improve the energy consumption structure. According to the results in Table 11, the negative relationship between green finance and traditional energy consumption can be confirmed. If the development level of green finance is increased by $1 \%$, the energy consumption will be reduced by $0.845 \%$, which is significant at the level of $1 \%$. The positive relationship between green finance and renewable energy consumption can also be confirmed. If the development level of green finance is increased by $1 \%$, the energy consumption will be increased by $1.309 \%$, which is significant at the level of $1 \%$.

5.6 Research on direct, indirect, and total effects of green finance development on energy consumption

Table 12. Direct effect, indirect effect, and total effect of spatial Durbin model

\begin{tabular}{|c|l|l|l|l|l|l|}
\hline & \multicolumn{5}{|c|}{ TEC } & \multicolumn{3}{|c|}{ REC } \\
\hline Variables & $\begin{array}{c}\text { Direct } \\
\text { effect }\end{array}$ & $\begin{array}{c}\text { Indirect } \\
\text { effect }\end{array}$ & $\begin{array}{c}\text { Total } \\
\text { effect }\end{array}$ & $\begin{array}{c}\text { Direct } \\
\text { effect }\end{array}$ & $\begin{array}{c}\text { Indirect } \\
\text { effect }\end{array}$ & $\begin{array}{r}\text { Total } \\
\text { effect }\end{array}$ \\
\hline GFI & $-0.840^{* * *}$ & -0.038 & $-0.879 * * *$ & $1.399 * * *$ & $2.178^{* * *}$ & $3.577 * * *$ \\
\hline LUR & $1.310^{* * *}$ & $-0.767 * *$ & 0.542 & -0.618 & 0.443 & -0.175 \\
\hline ISI & 0.015 & 0.040 & $0.056^{*}$ & -0.036 & -0.104 & -0.141 \\
\hline LGV & $-0.076^{* * *}$ & $0.157 * *$ & 0.080 & -0.102 & -0.252 & -0.355 \\
\hline LOPEN & -0.032 & -0.012 & -0.045 & -0.066 & -0.215 & $-0.281 * *$ \\
\hline TPI & $0.164 * *$ & $-0.344^{* *}$ & -0.179 & $0.164 * *$ & $-0.344 * *$ & -0.179 \\
\hline
\end{tabular}

$* \mathrm{p}<0.1, * * \mathrm{p}<0.05, * * * \mathrm{p}<0.01$

From Table 12, we can see that the direct and total effects of green finance development on traditional energy consumption are significant at the level of $1 \%$, while the indirect effects are not significant. This shows that the development of green finance in each province mainly contributes to the local energy conservation and emission reduction but has little impact on the reduction of traditional energy consumption in neighboring provinces. This implies that the spatial spillover effect of green finance on traditional energy consumption is not obvious.

We also can see that the direct, indirect and total effects of green finance development on renewable energy consumption are all significant at the level of $1 \%$. This shows that the development of green finance in each province has a certain spillover effect, which not only helps the local development of green energy, but also plays a good role in the production and utilization of clean energy consumption in surrounding provinces.

\section{Conclusions and suggestions}

This paper constructs China's GFI by selecting economic indicators, financial indicators and environmental indicators, and uses the improved entropy weight method to calculate the development level of green finance in China's provinces. It is found that the development level of green finance in China's provinces is on the rise, and there is a significant spatial spillover effect among provinces. Using multiple regression, panel regression and spatial Durbin model, it is found 
is, and the more the consumption of renewable energy is. Moreover, the development of green finance to promote the development of clean energy has a positive external effect. Therefore, we can vigorously develop green finance to optimize the energy structure.

Based on the existing research conclusions, this paper puts forward the following policy recommendations:

(1) Give full play to the spatial spillover effect of green finance in various regions of China, and build a perfect development model of green finance. Through the above research, we can find that there is a significant spatial spillover effect between different regions in China, and the cooperation between different regions effectively reduces the traditional energy consumption. From the research results, the development level of green finance in the eastern region is higher, while the development level of green finance in the western region is lower. Therefore, the western region should organize people to study the development path of green finance in the eastern region, but the western region can not copy the development model of the eastern region step by step. The western region should reasonably put forward relevant countermeasures according to the local actual situation, and strive to avoid detours. At the same time, the government should increase the support for green financial policy.

(2) Increase government support. From the above research results, it can be found that the active intervention of the government can reduce energy consumption to a certain extent. Therefore, the government should increase its support for green enterprises, guide more investors and funds into green enterprises through policy support, help green enterprises optimize industrial structure, promote enterprise technological progress and improve energy efficiency, so as to improve energy structure and reduce energy consumption.

\section{Acknowledgements}

The authors would like to thank Zhejiang science and Technology Information Research

\section{Availability of data and materials}

The data used to support the findings of this study are available from the corresponding author upon request.

\section{Author contribution}

Hui Wang contributed to the writing of this manuscript.

520 This paper is supported by Suqian Science and Technology Bureau(S202005). It also supported Lili Jiang contributed to the empirical study of this manuscript. Hongjun Duan contributed to the writing of this manuscript.

\section{Yifeng Wang contributed to the revision of this manuscript.}

Yichen Jiang contributed to the data collection of this manuscript.

\section{Funding} by Suqian-Taiwan Convergence Development Research Center. 


\section{Declarations}

Ethics approval and consent to participate: Not applicable.

Consent for publication: Not applicable.

Competing interests: The authors declare no competing interests

\section{Reference}

A, F. A. , \& B, S. A. . (2021). Energy consumption, finance, and climate change: does policy uncertainty matter?. Economic Analysis and Policy(4).

Abbasi, F. , \& Riaz, K. . (2016). Co2 emissions and financial development in an emerging economy: an augmented var approach. Energy Policy, 90(MAR.), 102-114.

Acheampong, A. O. . (2019). Modelling for insight: does financial development improve environmental quality?. Energy Economics, 83, 156-179.

Baa, B. , Li, Y. , Aoa, B. , \& Jkaa, B. . (2019). Investigating, forecasting and proposing emission mitigation pathways for co 2 emissions from fossil fuel combustion only: a case study of selected countries. Energy Policy, 130, 7-21.

Charfeddine, L. , \& Kahia, M. . (2019). Impact of renewable energy consumption and financial development on co2 emissions and economic growth in the mena region: a panel vector autoregressive (pvar) analysis. Renewable Energy, 139(AUG.), 198-213.

Cowan E . Topical Issues in Environmental Finance. Economy and Environment Program for Southeast Asia (EEPSEA), 1998.

Ozturk, I. . (2021). Finance and renewable energy development nexus: evidence from sub-saharan africa.

F Taghizadeh-Hesary, \& Yoshino, N. . (2019). The way to induce private participation in green finance and investment. Finance Research Letters.

Jeucken, M. . Sustainable Finance and Banking -Slow starters are gaining pace.

Jiang, L. , Wang, H. , Tong, A. , Hu, Z., Duan, H. , \& Zhang, X. , et al. (2020). The measurement of green finance development index and its poverty reduction effect: dynamic panel analysis based on improved entropy method. Discrete Dynamics in Nature and Society, 2020.

Jin L. Evaluation of Green Building Energy-Saving Technology Based on Entropy Weight Method[J]. Applied Mechanics \& Materials, 2017, 865:5.

Kaile, Zhou, Yiwen, \& Li]. (2019). Carbon finance and carbon market in china: progress and challenges. Journal of Cleaner Production.

Khan, M. , Yaseen, M. R. , \& Ali, Q. . (2017). Dynamic relationship between financial development, energy consumption, trade and greenhouse gas: comparison of upper middle income countries from asia, europe, africa and america. Journal of Cleaner Production, 161, 567-580.

Lei X, Qiu G. Empirical study about the carrying capacity evaluation of regional resources and environment based on entropy-weight TOPSIS model[J]. Acta Scientiae Circumstantiae, 2016.

Min W. et al. Measurement of Regional Green Economy Sustainable Development Ability Based on Entropy Weight-Topsis-Coupling Coordination Degree-A Case Study in Shandong Province, China[J]. Sustainability 2019 11(1), 280. 
Ozturk, I. . (2021). Finance and Renewable Energy Development Nexus: Evidence from SubSaharan Africa.

Rogger C , Beaurain F, Schmidt T S . Composting projects under the Clean Development Mechanism: sustainable contribution to mitigate climate change.[J]. Waste Management, 2011, 31(1):138-146.

Rovere, E. , Grottera, C. , \& Wills, W. . (2018). Overcoming the financial barrier to a low emission development strategy in brazil. International Economics on SciVerse ScienceDirect.

572 Salazar J . Environmental finance: Linking two world[J]. 1998.

Scholtens, B. . (2006). Finance as a driver of corporate social responsibility. Journal of Business Ethics, 68(1), 19-33.

Shahbaz, M. , Solarin, S. A. , \& Mahmood, H. . (2013). Does financial development reduce co2 emissions in malaysian economy? a time series analysis. Economic Modelling, 35(5), 145-152.

Shao, Q. , Schaffartzik, A. , Mayer, A. , \& Krausmann, F. . (2017). The high 'price' of dematerialization: a dynamic panel data analysis of material use and economic recession. Journal of Cleaner Production, 167(nov.20), 120-132.

580 Weiwei Li. et al. Sustainability Evaluation of Cities in Northeastern China Using Dynamic TOPSISEntropy Methods. Sustainability 2018,10(12), 4542

582 White, Rodney R. Environmental finance :[M]. J. Wiley, 2002. 